\title{
Preparation and Characterization of Tin(II) Complexes with Isomeric Series of Schiff Bases as Ligands
}

\author{
S. A. Sadeek ${ }^{\star}$ and M. S. Refat" \\ "Chemisn. Department, Foculh of Science, Zagaig Linwersin, Zagarig, Egrpt \\ Chemising Depatment, Faculy of Education, Sue-Canal Lninersin; Pont-Said, Egypt \\ (2005. 12. 12 접수)
}

\section{Preparation and Characterization of Tin(Ii) Complexes with Isomeric Series of Schiff Bases as Ligands}

\author{
S. A. Sadeek" and M. S. Refat* \\ "Chemisng Department, Foculh of Science, Zagarig Linnersing, Zagarig, Egpt

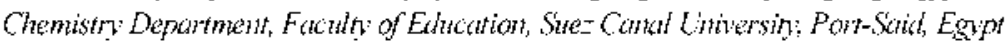 \\ (Received December 12, 2005)
}

요 약. $\mathrm{N}, \mathrm{N}^{*}-\mathrm{X}$-phenylenebisiacetylacetoneimine; $\left[\mathrm{X}=\right.$ ortho $\left(\mathrm{L}^{\prime}\right), \operatorname{meta}\left(\mathrm{L}^{3}\right)$ 및 para $\left.\left.\mathrm{L}^{3}\right)\right]$ 리간드를 갖는 즉석(II) 화 합물들을 합성하고, 그 특성을 원소분석, 적외선 분광광도법. 자외선가시광선 분광광도법 및 열분석법을 이횽하여 확인 하였다. 자외선 분광광도법을 동하여, 주어진 $\mathrm{ONNO}$ 주게 리간드들의 이민(imine) 및 카보널기의 배위 도드가 $C_{2 \mathrm{r}}$ 대 칭성을 갖는 것으로. 나터낪다. 또한 열분선 결과, $\operatorname{Sn}\left(\mathrm{L}^{3}\right)$ 화합물이 가장 높은 활성화 에네지를 가지는 반면, $\operatorname{Sn}\left(\mathrm{L}^{2}\right)$ 화 합눌이 가장 낮은 활성화 에네 지를 가짐을 알 수 있었다.

주제어: Schiff base, Tin(II) complex. Acetylacetonate derivatives, Spectroscopy. Thermal property. Activation energ

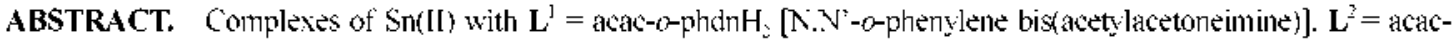

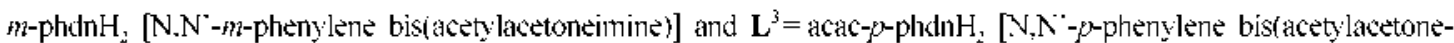
imine)] have been prepared and characterized by elemental analyses, vibrational, electronic spectra and themal studies (TGA and DTA). Vibrational spectra indicated the coordination mode of imine and cartonyl oxygen for ligands giving (ONNO) that belong to $\mathrm{C}_{2}$, point group symmetry. The [Sn( $\left.\mathrm{L}^{\hat{3}}\right)$ ] complex has a maximum activation energy and [ $\mathrm{Sn}\left(\mathrm{L}^{2}\right)$ ] complex has a minimum activation energy.

Keywords: Schift base, Tin(II) complex. Acetylacetonate derivatives. Spectroscopy. Themal property, Activation energy

\section{INTRODUCTION}

Schiff base are capable of forming coordinate bonds with many of metal ions through both azomethine group and phenolic group or via its azomethine or phenolic groups. ${ }^{1-3}$ Infrated spectroscopy has been widely used as a powerful means of distinguishing between the three possible donation sites of Schiff bases. A large number of Schiff bases and their complexes are significant interest and attention because of their biological activity including anti-tumor. antibacterial, fungicidal and anti-carcinogenic properties. ${ }^{+5}$ Tetradentate Schiff bases are well known to coordinate with various metal ions forming stable compounds. and some of these complexes are recognized as oxygen carriers.

To continue our investigation in the field of Schiff base complexes. ${ }^{711}$ we reported here preparation 
and characterization of the new complexes [Sn(acac-ophdn $\left.\left.\mathrm{H}_{3}\right)\right] \mathrm{Cl}$, $[\mathrm{Sn}(\mathrm{acac}-m$-phdn $\mathrm{H}),] \mathrm{Cl}_{3}$ and $[\mathrm{Sn}(\mathrm{acac}-p-$ phdn $\left.\left.\mathrm{H}_{2}\right)\right] \mathrm{Cl}_{2}$; (acac-o-phdnH $\mathrm{H}_{2}\left(\mathbf{L}^{\prime}\right)$, acac-m-phdn $\mathrm{H}_{2}$ $\left(\mathrm{L}^{2}\right)$ and acac-p-phdn $\mathrm{H}_{2}\left(\mathrm{~L}^{3}\right)$ are $\mathrm{N}_{1} \mathrm{~N}^{*}-o$-phenylenebis (acetylacetoneimine), N.N'-m-phenylenebis(acetylacetoneimine) and N,N'-p-phenylenebis(acetylacetoneimine, respectively). The solid products are well characterized through its elemental analysis, electronic spectra and thermal analysis, along with the assignment of their infrared spectra for most of the fundamental vibrations.

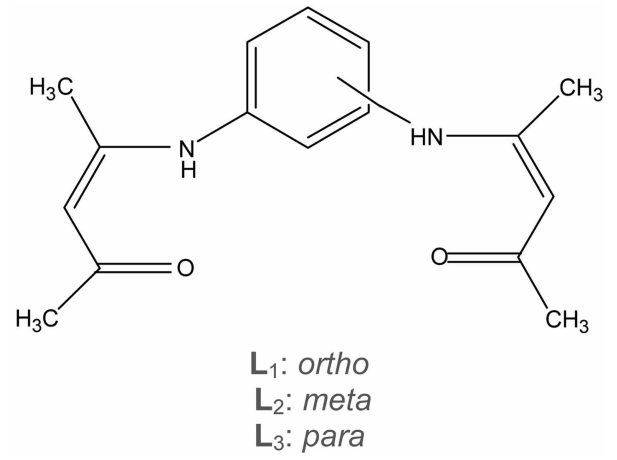

EXPERIMENTAL

All chemical used throughout this work were analytical reagent grade. The Schiff bases $\mathbf{L}^{\prime}$-acaco-phdnI I [N, ${ }_{2}$ '- - -phenylene bis(acetylacetoneimine)]. $\mathbf{L}^{2}$-acac-m-phdn $\mathrm{H}_{2}\left[\mathrm{~N}, \mathrm{~N}{ }^{*}\right.$-m-phenylene bis(acelylacetoncimine)] and $\mathrm{L}^{i}$-acac-p-phdnH., [N, $\mathrm{N}^{*}-p$ phenylene bis(acelylacetoneimine)] were prepared according to published method' ${ }^{2}$ from the condensation of $o$-phenylenediamine, $m$-phenylenediamine or $p$-phenylenediamine with acetylacetone in ethyl alcohol as a solvent. The separated precipitate was filtered, washed several times with minimum amount of ethyl alcohol and dried under vacum at room temperature. The isolated three Schiff bases were characterized through its infrared and elemental analysis. The deep pink solid complex [ $\left.\mathrm{Sn}\left(\mathrm{acac}-\mathrm{phdn}_{2}\right)\right] \mathrm{Cl}_{2}$ was prepared from the addition of $\operatorname{tin}([\mathrm{l})$ chloride (4 $\mathrm{mmol}$ ) in acetone to a stoichiometric amounts of the acac- $\alpha$-phdn $\mathrm{H}_{2},(\mathrm{l} .088 \mathrm{~g}, 4 \mathrm{mmol})$ in acetone. The mixture was then stirred at room temperature for about 6-8 hrs. The separated solid product was filtered off, washed several times with acetone and dried under vacuum. The other wo complexes [Sn(acac$m$-phdnH,)]Cl. (yellowish orange crystalline) and [Sn(acac- $p$-phdn $\mathrm{H}_{2}$ )]Cl, (brownish black) were prepared in a similar way to that described above by the reaction of tin(II) chloride with acac-m-phdn $\mathrm{H}_{2}$ and acac$p$-phdn $\mathrm{H}_{2}$, respectively. The complexes formed were characterized through their elemental analysis, infrared spectra as well as thermogravimetric (TG) and differential thermal analysis (DTA). Analysis of the products obtained is summarized in Table I. The percentage of tin was determined using atomic absorption method. $\Lambda \mathrm{n}$ atomic absorption spectrometer PYE-INNICAM SP 1900 litted with a tin lamp was used for this purpose. The inlrared specIra of the Schifl bases and tin(II) Schif] base complexes were recorded from $\mathrm{KBr}$ discs using a Perkin-f.Imer 1430 ratio recording infrared spectrophotometer. Thermogravimetric ( $\mathrm{JG}$ ) and differential thermal analysis (DTA) of the Schiff base complexes

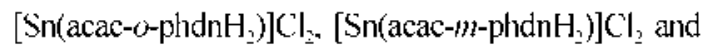
[Sn(acac-p-phdn $\left.\left.\mathrm{H}_{2}\right)\right] \mathrm{Cl}_{2}$ were carried out using a Shimadzu computerized thermal analysis system DT-40. The system includes programs that process data from the analyzer with the chromotpac C-R $3 \mathrm{~A}$. The rate of heating of the samples was kept at $5^{\circ} \mathrm{C} \mathrm{min'}$. Accurate samples were analyzed under a

Table I. The elemental analysis data

\begin{tabular}{|c|c|c|c|c|c|c|}
\hline \multirow{2}{*}{$\begin{array}{l}\text { Complexes } \\
\text { Elements }\end{array}$} & \multicolumn{2}{|c|}{ 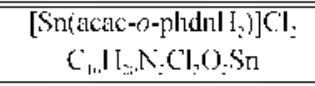 } & \multicolumn{2}{|c|}{$\begin{array}{c}\left.\left[\mathrm{Snn} \text { (acac- } m-\mathrm{phdnH} \mathrm{I}_{2}\right)\right] \mathrm{Cl}_{2} \\
\mathrm{C}_{1,} \mathrm{I}_{2,1} \mathrm{~N}_{2} \mathrm{Cl}_{3} \mathrm{O}_{3} \mathrm{Sn}\end{array}$} & \multicolumn{2}{|c|}{ 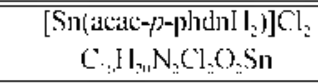 } \\
\hline & $\%$ Calc. & $\%$ Found & $\%$ Calc. & $\%$ Found & $\%$ Calc. & $\%$ Found \\
\hline$C$ & 41.58 & 41.53 & 41.58 & 41.56 & 41.58 & 41.54 \\
\hline II & 433 & 4.31 & 4.33 & 4.31 & 4.33 & 4.32 \\
\hline$N$ & 6.06 & 6.04 & 6.06 & 6.03 & 6.06 & 6.03 \\
\hline C1 & 15.37 & 15.34 & 15.37 & 15.35 & 15.37 & 15.31 \\
\hline $\sin$ & 25.70 & 25.65 & 25.70 & 25.62 & 25.70 & 25.59 \\
\hline
\end{tabular}


$\mathrm{N}$, flow at $40 \mathrm{ml}$ min ' $\alpha$-alumina powder was used as the DIA standard materials. Flectronic spectra of the reactants and products were recorded at room temperature using Jenway 6405 Spectrophotometer with quartz cell of I $\mathrm{cm}$ path length.

\section{RESULTS AND DISCUSSION}

The three new complexes $\left[\mathrm{Sn}\left(\mathrm{acac}-r_{-}\right.\right.$phdnI $\left.\left.\mathrm{I}_{2}\right)\right] \mathrm{Cl}_{2}$, $\left[\mathrm{Sn}\left(\right.\right.$ acac- $m$-phdn $\left.\left.\mathrm{I}_{2}\right)\right] \mathrm{Cl}_{2}$ and $\left[\mathrm{Sn}\left(\right.\right.$ acac-p-phdn] $\left.\left.\mathrm{I}_{2}\right)\right] \mathrm{Cl}_{2}$ formed in the reaction of $\mathrm{SnCl}_{2}$ with the Schiff bases acac- $\theta$-phdn $\mathrm{H}_{2}$, acac-m-phdnH, and acac- $p$-phdn $\mathrm{H}_{3}$ are characterized through their elenental analysis. infrared spectra and through their thermogravimetric investigation. The results enable us to characterize the complexes and make an assessment of the bonding and structures inherent in them.

The structural formula of these three complexes was obtained according to the following facts. Elemental analysis of the three complexes under investigation shows the presence of chloride ions in the three complexes. Solutions of these complexes react with silver nitrate giving a white precipitale of silver chloride indicating the existence of chloride in the ionic form i.e. outside the coordination sphere of the tin ion.

However, the Schiff bases under study may be present in tautomeric equilibrium (forms [-]II), which resemble the forms given by Dudek and Holm ${ }^{1.5}$ for similar Schiff bases.

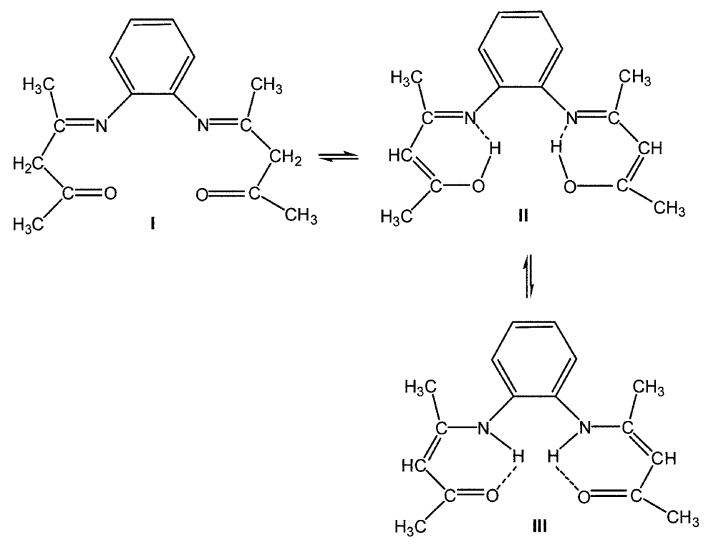

Distinction between the forms II and [I] is not large as a slight displacement of the hydrogen nucleus. It has been concluded from infrared evidences that similar Schiff bases are largely tautomerized into II and III with appreciable amount of each existing in the solid state and in solution. ${ }^{13 .} 14$

\section{Vibrational spectra}

Infrared spectra of the Schiff bases under studies give a broad absorption band at about $3170 \mathrm{~cm}^{-1}$. which may be due to the stretching vibration of either an $\mathrm{O}-\mathrm{H}$ group in accordance with formula II or an N-H group of the type indicaled by the formula I[I. Evidence of that ${ }^{1+}$ is found in the broadening of this band and shilt from normal positions (3700-3400 cm ' for free O-H and $3400-3300 \mathrm{~cm}^{\prime}$ for free $\mathrm{N}-\mathrm{H}$ ). Also the free Schiff bases do not absorb in the region of carbonyl group, thus the formula I is eliminated and the ligand is believed to be a tautomeric equilibrium mixture of structures [] and I[I.

The characteristic IR bands of [ $\mathrm{Sn}\left(\right.$ acac- 2 -phdn $\left.\left.\mathrm{H}_{2}\right)\right] \mathrm{Cl}_{2}$, $\left.\left[\mathrm{Sn}(\mathrm{acac}-m \text {-phdnI }]_{2}\right)\right] \mathrm{Cl}_{2}$ and $\left[\mathrm{Sn}\left(\mathrm{acac}-p\right.\right.$-phdnI $\left.\left.\mathrm{I}_{2}\right)\right] \mathrm{Cl}_{2}$ are shown in Table 2. Before explaining such assignments, the structures of these complexes must first be discussed. Bottcher et al. ${ }^{10}$ reported the crystal struclure of some related Schiff base complexes of Co(III) and indicated that the teradentate Schill base ligand (ONNO) coordinates the cobalt atom in a planar fashion with a slightly irregular tetragon with $\mathrm{Co}(\mathrm{III})$. The values of the $\mathrm{Co}-\mathrm{O}$ and $\mathrm{Co}-\mathrm{N}$ bond lengths in the equatorial ligand plane are 1.881 and $1.892 \mathrm{~A}^{\circ}$, respectively.

The complexes under investigations indicate that the tin(II) is only four coordinated and may take the structures shown in Scheme IV. With such structures the complexes may belong to $\mathrm{C}_{\mathrm{V}}$ symmetry and are expected to display 117 vibrational fundamental which are all monodegenerate. These are distributed between $A_{1}, A_{1}, B_{1}$ and $B$, motions; all are IR and Raman active, except for the A, modes, which are only Raman active.

In the spectra of the complexes, medium strong bands in the region $3340-3217 \mathrm{~cm}^{-1}$ do exist, Fig. 1 . These bands occur at lower frequency values known for $\mathrm{O}-\mathrm{H}$ groups, therefore, the two bands found at 3279 and $3217 \mathrm{~cm}^{-1}$ for the complex [Sn(acac- $r$ phdnH $\left.\left.\mathrm{H}_{2}\right)\right] \mathrm{Cl}_{2}$, and at $3320,3200 \mathrm{~cm}^{-1}$ for $[\mathrm{Sn}$ (acac- 


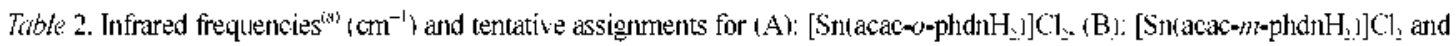
(C): [Sn(acac-ph-phdnI $I_{-}$] $\mathrm{Cl}_{2}$ complexes. complexes.

\begin{tabular}{|c|c|c|c|}
\hline \multicolumn{3}{|c|}{ Frequencies. $\mathrm{cm}^{-1}$} & \multirow{2}{*}{ Assignunents ${ }^{i t u}$} \\
\hline (A) & (B) & (C) & \\
\hline $\begin{array}{l}3279 \mathrm{~m} \\
3217 \mathrm{~m}\end{array}$ & $\begin{array}{l}3320 \mathrm{~ms} \\
3200 \mathrm{~m}\end{array}$ & $3340 \mathrm{~ms}$ & $V_{1}^{\prime}-x_{1}$ \\
\hline $\begin{array}{l}3150 w, 3095 w \\
3080 w, 3050 w \\
3020 w\end{array}$ & $\begin{array}{l}3080 \mathrm{nw}, 3060 \mathrm{nw} \\
3020 \mathrm{nw}\end{array}$ & $\begin{array}{l}3080 \times 4.3060 \mathrm{~W} \\
3030 \mathrm{~N}\end{array}$ & $v_{1 c-f} ;$ Phenyl \\
\hline $2960 \mathrm{w} .2915 \mathrm{w}$ & $\begin{array}{l}2960 w 2920 w \\
2880 w\end{array}$ & $\begin{array}{l}2970 w, 2920 w \\
2860 \mathrm{w}\end{array}$ & $v^{\prime \alpha .+] 1}:=C \mathrm{CH} . \mathrm{CH}_{3}$ \\
\hline $1630 \mathrm{~s}$ & $1630 \mathrm{vs}$ & $1605 \mathrm{~ms}$ & $v_{u_{4}=i_{1}, u_{1}}$ \\
\hline $\begin{array}{l}1590 \mathrm{~s} .1557 \mathrm{w} \\
1510 \mathrm{~m}\end{array}$ & $\begin{array}{l}1560 \mathrm{w}, 1525 \mathrm{~ms} \\
1500 \mathrm{~ms} .1490 \mathrm{~s}\end{array}$ & $\begin{array}{l}1550 \mathrm{w}, 1530 \mathrm{w} \\
1505 \mathrm{H.} 1495 \mathrm{w}\end{array}$ & $\begin{array}{l}v_{u}=c \\
\text { Phenlyl breathing modes }\end{array}$ \\
\hline $\begin{array}{l}1476 \mathrm{~m} .1425 \mathrm{~s} \\
1385 \mathrm{~s} .1357 \mathrm{~m}\end{array}$ & $\begin{array}{l}1440 \mathrm{~m} .1385 \mathrm{~m} \\
1345 \mathrm{ws} .1335 \mathrm{w} \\
1310 \mathrm{~ms}\end{array}$ & $\begin{array}{l}1475 \mathrm{sh} .1430 \mathrm{~ms} \\
1375 \mathrm{w}, 1360 \mathrm{~ms} \\
1315 \mathrm{~s}\end{array}$ & -CII. CH-defomatios \\
\hline $\begin{array}{l}1271 \mathrm{~m} .1244 \mathrm{~m} \\
1215 \mathrm{w} .1160 \mathrm{~m} \\
1110 \mathrm{~m}\end{array}$ & $\begin{array}{l}1260 \mathrm{w}, 1245 \mathrm{~ms} \\
1200 \mathrm{~m} .1155 \mathrm{~m}\end{array}$ & $\begin{array}{l}1285 \mathrm{H.} 1215 \mathrm{~s} \\
1170 \mathrm{~m} \cdot 1140 \mathrm{H} \\
1115 \mathrm{~ms}\end{array}$ & 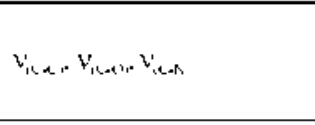 \\
\hline $\begin{array}{l}1045 \mathrm{~m} .1020 \mathrm{~m} \\
975 \mathrm{w.} 952 \mathrm{w} \\
884 \mathrm{w} .770 \mathrm{ws}\end{array}$ & $\begin{array}{l}1030 \mathrm{~m}, 940 \mathrm{w} \\
890 \mathrm{w} .880 \mathrm{w} \\
845 \mathrm{~ms} .775 \mathrm{w}, 720 \mathrm{w}\end{array}$ & $\begin{array}{l}1065 \mathrm{H.} 1020 \mathrm{~s} \\
950 \mathrm{~m} .925 \mathrm{~s} \\
850 \mathrm{~ms} .815 \mathrm{~s} \\
800 \mathrm{~Hz} .780 \mathrm{vs} \\
755 \mathrm{~ms} .733 \mathrm{~ms}\end{array}$ & CH-bend: Phenll. CH, \\
\hline $\begin{array}{l}656 \mathrm{w} \\
628 \mathrm{mw}\end{array}$ & $\begin{array}{l}675 \mathrm{w} \\
600 \mathrm{~m}\end{array}$ & $\begin{array}{l}690 \mathrm{w} 670 \mathrm{vs} \\
590 \mathrm{~W}\end{array}$ & CH- itl-plane bend: Phenlyl \\
\hline $5 \mathrm{l} 4 \mathrm{mw}$ & $555+4$ & $550 \mathrm{H}$ & $v_{* 1 ;}:$ O of Schiff hase \\
\hline $475 w$ & $490 w$ & $\begin{array}{l}505 \mathrm{~ms} \\
480 \mathrm{w}\end{array}$ & $v_{* 1 \leqslant-1,2} O$ of Schiff hase \\
\hline $\begin{array}{l}428 \mathrm{mw}, 405 \mathrm{mw} \\
394 \mathrm{w}, 366 \mathrm{mw} \\
\end{array}$ & $410 \mathrm{nt} .400 \mathrm{wn}$ & $\begin{array}{l}425 \mathrm{~m} \\
395 \mathrm{~m} \\
\end{array}$ & $\mathrm{CH}$ - out of plane bend \\
\hline $\begin{array}{l}345 \mathrm{~s} \\
320 \mathrm{~m} \\
295 \mathrm{~m} \\
265 \mathrm{~s}\end{array}$ & $\begin{array}{l}325 \mathrm{kw} \\
315 \mathrm{Ww} \\
300 \mathrm{w}\end{array}$ & $\begin{array}{l}350 \mathrm{HF} \\
330 \mathrm{~N} \\
290 \mathrm{HF}\end{array}$ & $\begin{array}{l}v_{\text {sates }}: N \text { of Schiff base } \\
v_{\text {sisen }}: N \text { of Schiff base }\end{array}$ \\
\hline
\end{tabular}

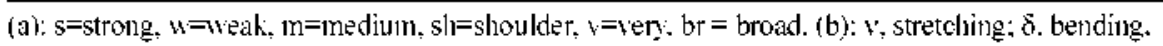

$\left.\left.m-p h d n \mathrm{H}_{2}\right)\right] \mathrm{Cl}_{2}$ and $3340 \mathrm{~cm}^{-1}$ for $\left[\mathrm{Sn}\left(\right.\right.$ acac-p-phdn $\left.\left.\mathrm{H}_{2}\right)\right] \mathrm{Cl}_{2}$ complexes, respectively, are assigned to coordinated N-H groups. I' Accordingly, the three complexes under study have coordinated $\mathrm{N}-\mathrm{H}$ groups which indicated that. the Schiff bases under study coordinates with $\mathrm{Sn}(\mathrm{II})$ as a tetradentate through the two nitrogen and oxygen atoms as shown in Scheme IV and in the ketoamine form (III).

The $v(\mathrm{C}-\mathrm{H})$ for the phenyl group are assigned in the region $3150-3020 \mathrm{~cm}^{-1}$. Table 2, while those for the $\mathrm{CH}_{3}$ and $=\mathrm{CH}$ - groups are shown as expected at
2970, 2960, 2915, 2880 and $2860 \mathrm{~cm}^{-1}$. The carbonyl bands $v(C=O)$ of our complexes are shown at 1630 and $1605 \mathrm{~cm}^{-1}$ as a strong and medium strong band. The $v(\mathrm{C}=\mathrm{C})$ stretching vibrations and pheny] breathing modes of the three complexes are observed in the range $1590-1490 \mathrm{~cm}^{-1}$. The bending vibrations. $\delta\left(-\mathrm{CH}_{3}\right)$ and $(=\mathrm{CH})$ are observed in the region 1476-13 $10 \mathrm{~cm}^{-1}$. The description of their assignments follow the expression developed and used by others. ${ }^{1 ? .18}$

The stretching vibrations of $v(\mathrm{C}-\mathrm{O}), v(\mathrm{C}-\mathrm{C})$ and 


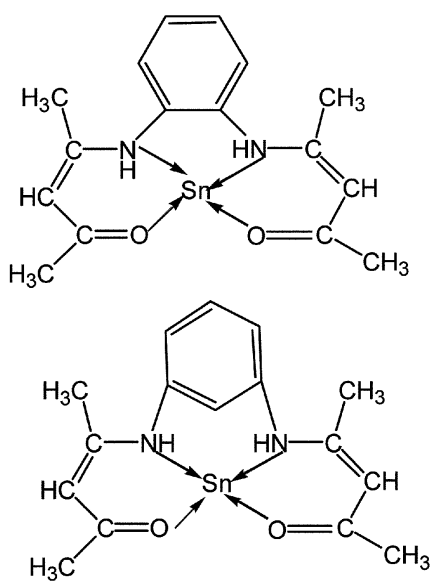

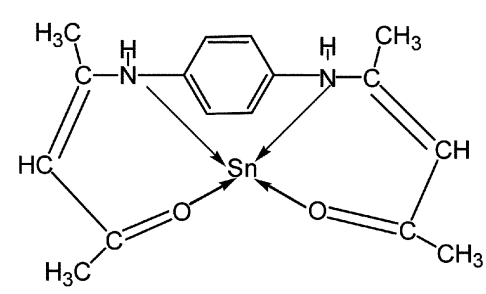

Scheme IV

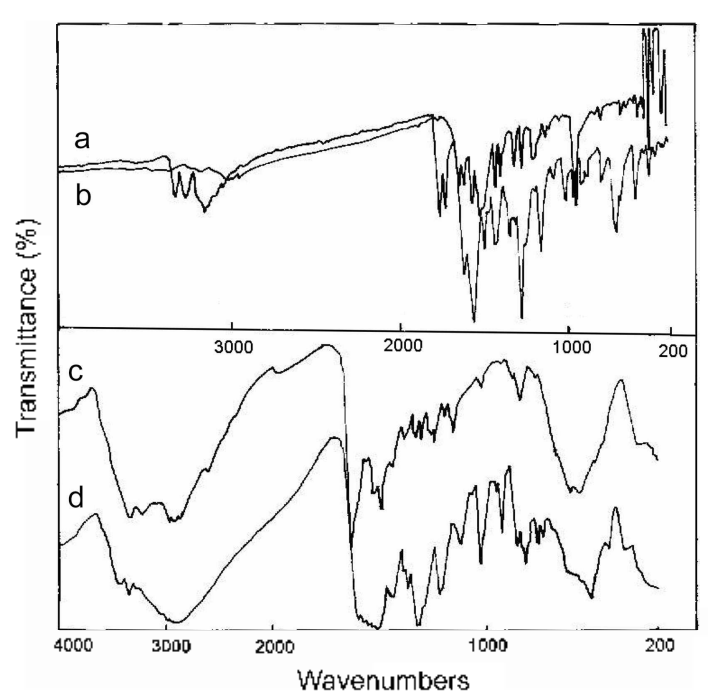

Fig. 1. Infrared spectra of (a): acac-o-phdnl $I_{2}$ Schiff base, (b):

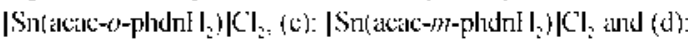
ISn(acac-p-phdn $\left.\mathrm{I}_{2}\right) K \mathrm{Cl}_{2}$ complexes.

$v(\mathrm{C}-\mathrm{N})$ occur in the region $1285-1110 \mathrm{~cm}^{\prime}$, Table 2. The tin-oxygen ( $\mathrm{O}$ of Schiff base) stretching vibration, $v_{\alpha}(\mathrm{Sn}-\mathrm{O})$ are assigned for the three complexes at
514,555 and $550 \mathrm{~cm}^{~}$, while the corresponding $v_{3}(\mathrm{Sn}-\mathrm{O})$ are assigned at 475,490 and $505,480 \mathrm{~cm}^{\prime}$ for $\mathrm{o}^{-}, \mathrm{m}$ - and $\mathrm{p}$ - Schiff base complexes, respectively. The $v_{15}(\mathrm{Sn}-\mathrm{N})$ are assigned at $345,320 \mathrm{~cm}{ }^{\prime}$ and $325,315 \mathrm{~cm}^{-1}$ and $350,330 \mathrm{~cm}$ ', for our study complexes, while $v_{s}(\mathrm{Sn}-\mathrm{N})$ are assigned to the strong and weak infrared bands around $295 \mathrm{~cm}^{-1}$. The assignments of these metal-ligand stretches are made on the basis of their activities as well as the relative bond strengths shown from the crystal structure data known ${ }^{16}$ for some related schiff base conplexes, and also that the assigned bonds do not exist in the free ligand spectra. However, the v(Sn-N) stretches were assigned at relatively low frequency values compared to $v(\mathrm{Sn}-\mathrm{O})$. This is in agreement with the bond length values, which indicate that the Sn-N bond is the weakest with a large value of bond length.

\section{Thermal studies}

Differential thermal analysis (DTA) and thermogravimetric (TG) were measured for the three complexes to investigate the mode of decomposition of these types of complexes, Fig. 2. The maximum temperature values $\mathrm{T}_{\max } /{ }^{\circ} \mathrm{C}$ logether with the corresponding weight loss for each step of the decomposition are recorded in Table 3. The decomposition of the complex $\left[\mathrm{Su}\left(\mathrm{acac}-\mathrm{o}\right.\right.$-phdn $\left.\left.\mathrm{H}_{2}\right)\right] \mathrm{Cl}_{2}$, falls in one degradation stage. This stage of decomposition appears at two maxima 120 and $165^{\circ} \mathrm{C}$ is associated with a weight loss of $54.96 \%$ corresponding to the loss of $5 \mathrm{C}_{2} \mathrm{I}_{2}, 2 \mathrm{ICl} \cdot 2 \mathrm{NH}_{3} \mid \mathrm{I}_{2} \mathrm{O}$. The weight loss in this stage $54.96 \%$ is in full agreement with the calculated value of $55.23 \%$. The thermal degradation for the other wo complexes, [Sn(acac-m-phdn $\left.\left.\mathrm{H}_{2}\right)\right] \mathrm{Cl}_{2}$ and $\left[\mathrm{Sn}\left(\mathrm{acac}_{-}-\mathrm{p}\right.\right.$-pdn $\left.\left.\mathrm{H}_{2}\right)\right] \mathrm{Cl}_{3}$, exhibit approximately one main decomposition step. Fig. 2, this stage of decomposition occurs at maximum temperatures 141,259 and $109,153^{\circ} \mathrm{C}$, respectively, and acconpanied by a weight loss of 47.11 and $66.16 \%$ correspond to the loss of $3 \mathrm{C}_{2} \mathrm{H}_{4}+2 \mathrm{HCl}+2 \mathrm{NH}_{3}+\mathrm{CO}$ and $7 \mathrm{C}_{2} \mathrm{H}_{2}+2 \mathrm{HCl}-\mathrm{N}_{2}-\mathrm{H}_{2} \mathrm{O}+\mathrm{H}_{2}$ in agreement with our predicted weight loss of 47.44 and $65.63 \%$ for $\left[\mathrm{Sn}\left(\right.\right.$ acac-m-phdnH $\left.\left.\mathrm{H}_{2}\right)\right] \mathrm{Cl}_{2}$ and $\left[\mathrm{Sn}\left(\right.\right.$ acac- $p$-phdnI $\left.\left.I_{2}\right)\right] \mathrm{Cl}_{2}$ complexes, respectively. The above going conclu- 

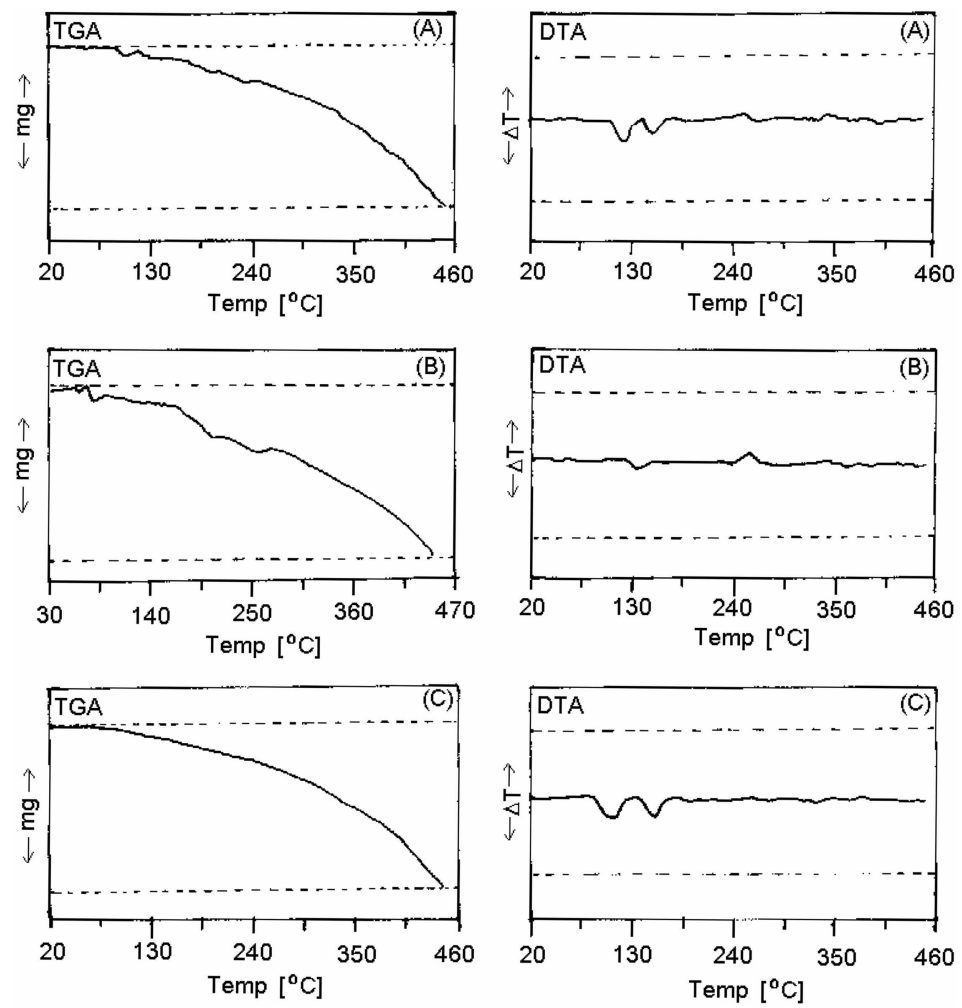

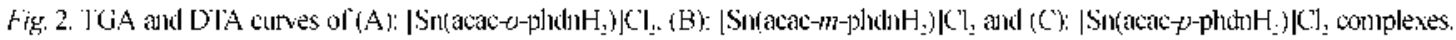

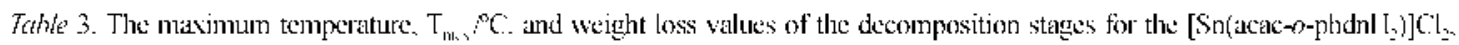
$\left.\left[S \operatorname{sicac}-m-p h d n I_{2}\right)\right] C l_{2}$ and $\left[S \operatorname{Su}\left(a c a c-p-p h d n I I_{2}\right)\right] C I_{2}$ complexes.

\begin{tabular}{|c|c|c|c|c|c|}
\hline \multirow{2}{*}{ Complexes } & \multirow{2}{*}{ Decomposition } & \multirow{2}{*}{$\mathrm{T}_{\text {winin }} / \mathrm{C}$} & \multirow{2}{*}{ I.ost species } & \multicolumn{2}{|c|}{ \%Weight losses } \\
\hline & & & & Found & Calc. \\
\hline \multirow[t]{3}{*}[\operatorname{Sn}(\text{acac-o-phdn}\mathrm{H}_{-})]{$C \mathrm{C}_{-}$} & First stage & $\begin{array}{l}120^{\circ} \mathrm{C} \\
165^{\circ} \mathrm{C}\end{array}$ & $\begin{array}{l}\left.5 \mathrm{C}_{2}\right] \mathrm{I}_{2} \\
2 \mathrm{ICl} \\
2 \mathrm{NI} \mathrm{I}_{3} \\
\left.\mathrm{I}_{3} \mathrm{O}\right)\end{array}$ & $54.96 \%$ & $55.23 \%$ \\
\hline & Total loss & & & $54.96 \%$ & $55.23 \%$ \\
\hline & Residure & & & $45.04 \%$ & $44.77 \%$ \\
\hline \multirow[t]{3}{*}[\operatorname{Sn}(\text{acac-m-phdnl}I_{-})]{$C]$} & First stage & $\begin{array}{l}141^{\circ} \mathrm{C} \\
259^{\circ} \mathrm{C}\end{array}$ & $\begin{array}{l}3 \mathrm{C}_{\mathrm{II}} \\
2 \mathrm{HCl} \\
2 \mathrm{NH} \\
\mathrm{CO}\end{array}$ & $47.11 \%$ & $47.44 \%$ \\
\hline & Total loss & & & $47.11 \%$ & $47.44 \%$ \\
\hline & Residue & & & $52.89 \%$ & $52.56 \%$ \\
\hline \multirow[t]{3}{*}[\text{Sin}(\text{acac-}p\text{-phdnl}I_{2})]{$C I_{2}$} & First stage & $\begin{array}{l}109^{\circ} \mathrm{C} \\
153^{\circ} \mathrm{C}\end{array}$ & $\begin{array}{l}7 \mathrm{C}_{2} \mathrm{H}_{2} \\
2 \mathrm{HCl} 1 \\
\mathrm{~N}_{2} \\
\mathrm{II}_{2} \mathrm{O} \\
\mathrm{II}_{2}\end{array}$ & $66.16 \%$ & $65.63 \%$ \\
\hline & Total loss & & & $66.16 \%$ & $65.63 \%$ \\
\hline & Residue & & & $33.84 \%$ & $34.37 \%$ \\
\hline
\end{tabular}


sion was also supported by the fact that the infrared spectra of the final decomposition products for the complexes under investigation shows the absence of all bands associated with the Schiff base ligands and instead the characteristic spectrum of SnO is appeared. Accordingly, the following mechanisms are proposed for the thermal decomposition of the Schiff base complexes as follows:
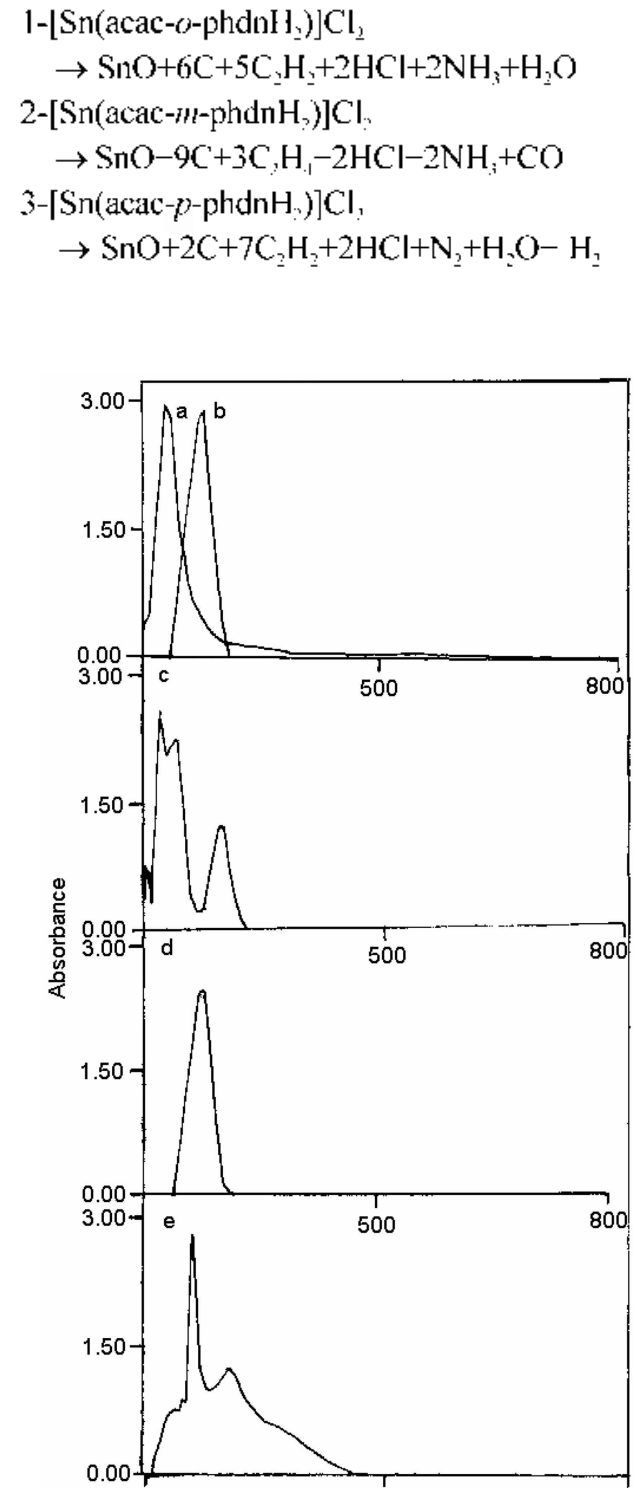

Fig. 3. Electrotic spectra of (a): SnC. I, (b): Acelylacetonate. (c): acac- $-\rho-\mathrm{ph} d \mathrm{~h} \mathrm{H}_{-}$, (d): acac-o-phenylenedianine, (e): Acetylacetonateto- phenylencdiamine / $\mathrm{SnCl}$, complex.

\section{Electronic spectra}

The electronic spectra of the $\mathrm{SnCl}$, acetylacetonate, schiff base (e.g, acac-o-phdn $\mathrm{H}_{2}$ ) and the com-

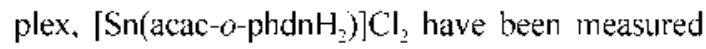
in methanol as a solvent, Fig. 3. The spectra of the uncomplexed ligand (acac- $\sigma$-phdn $\mathrm{H}_{2}$ ) show a characteristic band at $275 \mathrm{~nm}$ which is assigned to $\mathrm{n} \rightarrow \pi^{*}$ transition to the chromophoric $\mathrm{C}^{-} \mathrm{O}$ group. This band shows a bathochromic shift in the tin(II) complexes of all the ligands. This is attributed to the involvement of carbonyl group in metal complexation as indicated by IR studies. The Schiff bases, acac-o-phdn $\mathrm{H}_{3}$ acac- $m$-phdnH, and acac- $p$-phdn $\mathrm{H}_{3}$ were prepared in this study play a role of donor type (n-donor). The n-donor is neutral, even systems containing relatively an easily ionized atomic lone pair of electrons. ${ }^{19}$ The donated electrons come from a non-bonding molecular orbital occupied in the original donor by a lone pair of electrons as follows:

$$
\mathrm{n}+\mathrm{A} \rightarrow \mathrm{n} \cdot \mathrm{A} \leftrightarrow \mathrm{n}^{-}-\mathrm{A}
$$

On the other side tin(II) chloride reacted as a vacant orbital acceptor ${ }^{10}$ which is neutral even system or even ions in which an orbital or orbitals of relatively high electron allinily are vacant. This type of acceptors combine especially with n-donors to form fairly stable compounds by partial dative acceptance of electron into vacant orbital as follows:

$$
\mathrm{D}:-\mathrm{V} \rightarrow \mathrm{D}: \mathrm{V}
$$

To make a comparison between reactants and products (Fig. 3), there are three electron spectra bands observed around 260 and $310 \mathrm{~nm}$ due to $\pi \rightarrow \pi^{*}$ of acetylacetonate ring $\left(\mathrm{C}^{-} \mathrm{O}\right)$ and at around $379 \mathrm{~nm}$ as shoulder broad peak due to the metal-toligand charge transfer transition. bases and $\mathrm{SnCl}$, (the color of schill base widely change as soon as tin(II) chloride added from brownish yellow to pink color).

\section{Kinetic calculation}

From TGA curves, the order $(n)$, activation energy $\left(E^{\circ} / \mathrm{kJ} \mathrm{mol}^{\prime}\right)$, and the pre-exponential factor, $Z$, for thermal reactions of the complexes have been elucidated by linearisation method of Horowitz-Metzger 

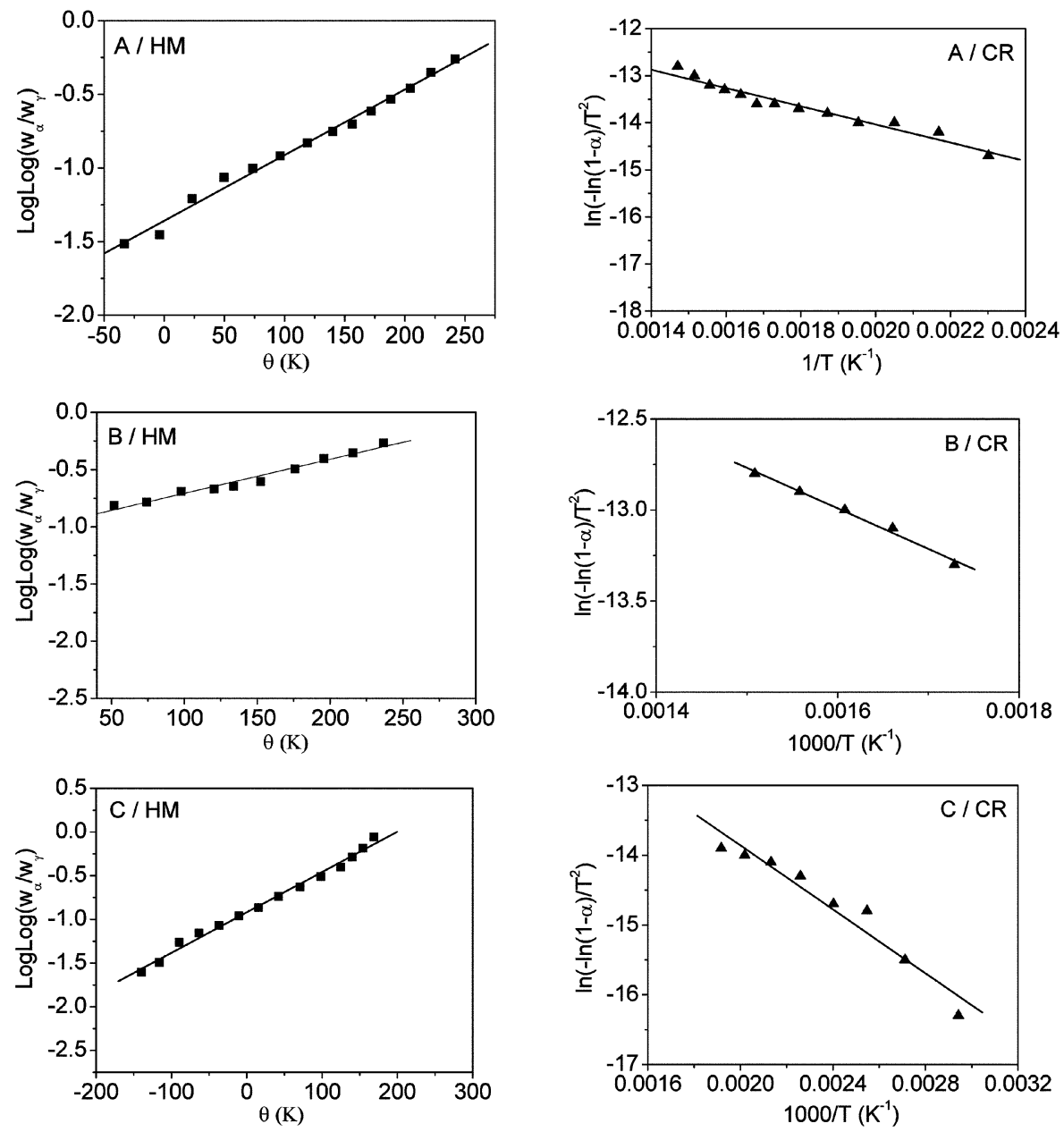

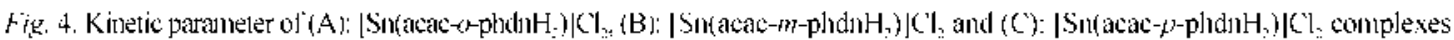
using Horow itz-Metzger (HM) approximation mellod and Coats-Redlem (CR) integral method.

Fable 4. Kinetic parameters deternined using the Coats-Redletn (CR) and Hotowilz-Metzger (HM).

\begin{tabular}{|c|c|c|c|c|c|c|c|c|c|c|c|}
\hline \multirow[b]{2}{*}{ Complex } & \multicolumn{5}{|c|}{ I lorowilz-Metzer } & \multicolumn{5}{|c|}{ Coats-Redlen } & \multirow[b]{2}{*}{$n$} \\
\hline & $\begin{array}{c}\mathrm{C} / \\
\text { k.lTוmol }\end{array}$ & $\begin{array}{l}Z / \\
s^{-1}\end{array}$ & $\begin{array}{c}\Delta S \\
J^{\prime} \mathrm{m}^{-1} \mathrm{~K}^{-1}\end{array}$ & $\begin{array}{c}\Delta \mathrm{HI} \\
\text { k.lnol } \\
\end{array}$ & $\begin{array}{c}\Delta \mathrm{Gi} \\
\mathrm{kJ}_{\mathrm{J} m \mathrm{I}^{-1}}\end{array}$ & $\begin{array}{c}\text { C/ } \\
\text { k. } \ln 1 \mathrm{Ol}^{-1}\end{array}$ & $\begin{array}{l}\mathrm{Z} \\
\mathrm{s}^{-1}\end{array}$ & $\begin{array}{c}\Delta S / \\
{\left[m, l^{-1} K^{-1}\right.}\end{array}$ & $\begin{array}{c}\Delta \mathrm{II} / \\
\mathrm{k} \cdot \mathrm{Jno \textrm {I } ^ { - 1 }}\end{array}$ & $\begin{array}{c}\Delta \mathrm{Co}^{\prime} \\
\mathrm{k} \cdot \mathrm{mol} \mathrm{l}^{-1}\end{array}$ & \\
\hline LI & 16.4 & $2.28 \mathrm{E}-\mathrm{I}$ & -260 & 12.7 & 127 & 16.1 & $1.25 \mathrm{E}+7$ & -254 & 12.5 & 122.6 & I \\
\hline $\mathrm{L} 2$ & 10.4 & $3.20 \mathrm{E}-2$ & -277 & 6.82 & 125 & 10.5 & $6.94 E+6$ & -265 & 6.2 & 120.8 & I \\
\hline L3 & 25.1 & $7.65 \mathrm{E}-1$ & -252 & 20.6 & 155 & 24.6 & $6.13 E+6$ & -220 & 19.6 & 149 & I \\
\hline
\end{tabular}

(HM) approximation method and Coats-Redfern integral method. ${ }^{21.22}$ The entropy of activation $\Delta S^{*}$ in $\left(\mathrm{JK}^{-1} \mathrm{~mol}^{-1}\right)$ was calculated by using the equation: $\Delta S^{*}=R \ln \left(A h k_{B} T\right)$, where $k_{k}$ is the Boltzmann constant, $h$ is the Plank's constant and $T$ is the DTA peak temperature.
The enthalpy activation, $N H^{*}$, and Gibbs free energy, $\Delta G^{*}$, were calculated from; $\Delta H^{*}=E^{*}-R T$ and $\Delta G^{*}=$ $\Delta H^{*}-T \Delta S^{*}$, respectively. The data is presented in Fig. 4 and Table 4. The complexes with all the ligands start decomposing in the range $382-583 \mathrm{~K}$. This shows that the complexes are anhydrous. $\mathrm{Nll}$ 
complexes decomposed via first order kinetics and energy of activation is $16-25 \mathrm{kJmol}^{-1}$. The order of activation energy is: $\mathbf{L}^{2}>\mathbf{L}^{\mathrm{l}}>\mathbf{L}^{2}$ for tin(II) complexes. The literatures contain various explanations of the relative order of thermal stability of complexes. ${ }^{2+26}$ The final product of the decomposition in all the complexes is SnO as confitmed by experimental and calculated weight losses.

\section{REFERENCES}

1. Sheat, S. V.: Waters. T. V.. J. Inorg, Nucl Chent. 1964, 26. 1221

2. Cozens, R. J.: Wurray. K. S.: West, B. O.. Organontet. Chtem. 1971, 27, 399.

3. Bigotto. A.: Galasso. V.: Dealti. G. Spectrochim. Ack, 1972, 28.t, 1581.

4. Re11. S.: Wano. R.: Komatsu. K.: Bonaz-Krause, P.: Zy rianov, Y.: McKenna, C. E.: Csipke. C.: Tokes, Z. A.: Lien, E. J., J. Hed. Chem. 2002. $+5,410$.

5. Raman, N.: Thangaraja, A.: Kulandaisamy, C.. Trans. Met. Chem, 2003, 28, 29.

6. Fleriani, C.: Calderazzo, F.. J. Chen. Soc. (A), 1969, 949.

7. Saderti S. A.: Teleb, S. M.. J. Phys Chem. Solids, 1993, 5t, 489.

8. Teleb, S. M.: Sadere S. A.: Nour, E. M., Spectroscopic Lett., 1993, 26, L), 169.

9. Sadeek S. A.: Refat M. S.: Teleb, S. M., Bull. Chem. Soc. Ethiop. 2004, $18(2), 149$.

10. Saderk, S. A.: Teleb, S. M.: Refat, M. S.: Elmosallany,
M. A. F. J. Coond. Chem, 2005, 58(12), 1077.

11. Sadeek. S. A.: Teleb. S. M.: Al-kority. A. M.. J. Indikn Soc. 1993, 70.63.

12. McCarthy. P. J.: Havey. R. J.: Ueno, K.: Martell, A. E., J. Am. Chem. Soc, 1955. 77. 5820.

13. Dudek. G. O.: Holm. R. H.. J. Am. Chem. Soc. 1961. 5. 1955.

14. Ueto, K.: Martell, A. E., J. Phys. Chem., 1955, 59, 998.

15. Martell, A. E.: Belford, R. L.: Calvin, M., I. Horg. Wict. Chem., 1958, 5, 170.

16. Bottcher, A.: Takeuchi, T.: f lardcastle, K. L.: Meacle, T. I.: Gray, II, B., Ihorg. Chem., 1997, 36, 2498.

17. Colthup, N. B.: Daly, L. I I.: Wiberly, S. E. Introduction of Infiared and Raman spectroscopy, Academic. New York, 1975.

18. Datta, M.: Bronn, D. Il.; Smith, W. E., Spectrochinn. $A c t a, 1983,39,37$.

19. Foster, R.: Organic Charge-Transfer Complexes, Academic Press, London and New York, 1969.

20. Khalil, M. M. Il.: Aboaly, M. M.: Ramadan, R. M., Spectrochin. Acta, 2005, 61A, 157 .

21. J Iorowiz, II. W.: Metger, G, Anat. Chem., 1963, 35, 1464.

22. Coats, A.W. Redfern, J. P.. Nature 1964, 68, 201.

23. Flym, J. H. F.: Wall. L. A., J. Res. Natl. But Sond.. $1996,70 \mathrm{~A} .487$.

24. Botti, S. R.; Quana, D., J. Inorg. Nucl. Chen. 1964. 26. 1919.

25. Shashagiri, V.: Rao. S. B.. Z. And. Chem 1972. 262. 175.

26. Naidu, R.S.: Naidu, R.R., Indian J. Chen. 1977, 15A. 652. 